a fresh tapping of the appropriate busbar system. Lighting points are fed from the same source, but are separately fused. Colour differentiation is employed. for all services.

Heating and ventilating of the building are effected by low-pressure steam radiators and the central plenum installation, the latter forcing filtered and tempered air through ducting following the route of the general services. Vitiated air is thus displaced, each room having inlet and exit grilles at high level. The ducts pass centrally along corridors, the whole being enclosed by false ceilings, with removable access panels along the whole length, the voids on each floor communicating with the exit air shaft discharging at roof-level.

A brief summary of the field of chemical and physical research covered by the Chemistry Departmont was given at the opening ceremony by Dr. T. P. Hughes, the present head of the Department. As a specialist department of the R.A.E., the Chemistry Department must be prepared to offer chemical advice and services to all departments of the Royal Aircraft Establishment and to certain departments of the Ministry of Supply ; both these functions have been discharged with some notable successes in the past. Much of the work is necessarily of a short-term and ad hoc nature; but roughly speaking about half the effort of the Department is directed along fairly long-term lines and includes a healthy proportion of basic chemical and physical research.

The Chemistry Department is responsible for much of the development and application of non-metallic materials to aircraft, and under Mr. H. W. Hall is a section specializing in the chemistry and physics of such solids as plastics, rubber, wood and adhesives. Recent developments in high-speed flight have emphasized the value of maintaining smooth surfaces on thin highly stressed wings, and it has been considered that reinforced plastic structures might possess many production and operational advantages over the conventional metal wing. To develop this specific application, and also to examine the possibilities of plastic structures for all airframe requirements, a section under Mr. J. E. Gordon is attempting to make a few large-scale structures in reinforced plastics. A related field is that of textiles, where a section under Mr. J. W. W. Dyer is covering certain aspects of the development and performance of textiles and proofed fabrics.

The physics and chemistry of the many special fluids used in civil and military aircraft, such as paints, fuels, hydraulic fluids, lubricating oils and greases, are being studied in a section under Dr. E. W. J. Mardles. Much of the work is concerned at present with the rheological behaviour of these fluids. The assessment and reduction of fire risks in aircraft is the major function of a section directed by Mr. W. G. Glendinning. A section under Dr. J. D. MainSmith covers miscellaneous chemical problems, chiefly of an inorganic nature. Among many other successes, this group developed the simple chemical carbon monoxide indicator which is widely used for aircraft cabin-contamination tests.

The chemistry of the reactions liberating energy in various forms of aircraft power plant is being investigated in a section under Dr. W. G. Parker. In the same manner as the development of piston engines and their fuels has been materially assisted by the understanding of the combustion process gained by some twenty years of physico-chemical research, it is hoped to obtain some insight into the combustion processes in later power plants, such as gas turbines, ram jets and rockets, for here the greater simplicity of the mechanical design has considerably increased the scope of the chemist.

In his address, Mr. G. R. Strauss emphasized the importance of scientific research in the aircraft field, and declared that the Government would continue to give every support to aeronautical research and development. In the new laboratory he hoped that the chemists and physicists would find congenial working conditions for the important part they have to play in aeronautical research of the future.

\section{GOVERNMENT RESEARCH IN BRITAIN}

WHILE the veil of secrecy drawn for the most part over the activities of the Department of Scientific and Industrial Research since the spring of 1939 remains unlifted, and we still await the resumption of publication of the annual reports of the Department and even the appearance of the long. promised review of its war-time activities, pronouncements regarding administrative developments are made in diverse ways and sometimes to strange audiences. The address of the Lord President of the Council to the North Herts Labour Party at Letchworth on January 14, containing the important announcement regarding the development of a scientific centre at the new town of Stevenage, is a recent example. Mr. Morrison prefaced his announcement by stating that the Government is eager to see science supporting enterprise in the national effort for economic recovery and independence. It proposes to bring to public enterprise new ideas and progressive development by making full use of the unrivalled scientific brains of Britain, sweeping away the old isolation of science and the tendency to look at scientific workers as people not needed in industry or only needed in the 'back room', or as long-haired. old gentlemen cut off from worldly affairs. The Government is taking steps, he said, to bring science into the forefront of British industry, and does not believe that industry can give the nation what it wants in increasing abundance at decreasing costs unless science becomes more of a partner.

Mr. Morrison referred to the recent increase in the number and the effectiveness of the research associations in industry, and to the way in which the National Coal Board has brought science into the coal-mining industry at the top level and in every area. He looked to the time when every British worker will be conscious that he has a scientific man close at hand to make his work easier and less unpleasant, and to help him to get a better result. Although it would be some time before British industry could be re-equipped, even existing plant could be made much more productive by the assist. ance of science.

Mr. Morrison emphasized that time would also be required before fundamental research now being carried out could show results in industry; in the meantime, he said, we must rely chiefly on the more effective use of the vast amount of scientific knowledge which already exists, but which has not yet been fully applied in British industry, and on harnessing the social sciences to help managements and workers in their daily problems. Here the Lord President instanced the contribution of housing research under 
the Department of Scientific and Industrial Research in raising standards of comfort in housing, and to the investigations of the Shirley Institute into the productivity of different cotton mills. The latter investigations had suggested that by bringing the practices of all mills up to those of the best, the output of the present labour force and machinery might be inereased by not less than ten, and possibly as much as forty, per cent. Mr. Morrison also referred to the work of the Industrial Health Research Board on lighting and fatigue, and in particular to the value of choosing the right colours for machines and working equipment in reducing fatigue and increasing output.

The organisation of science is also important, and the Lord President, after paying a tribute to the work of the Advisory Council on Scientific Policy, referred to the programme of the recently established Committee on Industrial Productivity and its various panels. If science, however, is to be at the heart of industrial effort in Britain, it is also necessary for the nation to understand, use and continually demand the fruits of science. He said that the new developments mentioned represent a start towards making Britain a truly scientifically minded nation, with all the advantages which flow from that. We must in future be accustomed to setting aside for science larger resources and more man-power if we are to get the maximum results. Much of our scientific research had been carried on under very bad conditions, and the Govermment is taking steps to improve those conditions as fast as possible. Recently, he said, he had arranged for the largest of our new scientific stations - that for mechanical engineering researchto be located in Scotland. It is important that scientific research and the inspiration it brings should be well distributed over the country, although many of our research establishments must of necessity be in the London region.

The Government has decided, Mr. Morrison said, that the new town at Stevenage should be given preference in considering the sites of new scientific establishments in the London region. A number of research stations would have to move from their present sites, which they have outgrown. He was unable to say what actual research will be located at Stevenage; but the town will become one of the important scientific centres of the future. Letchworth, since its earliest days, has been the home of industries characterized by a progressive attitude to research, and he hopes that those industries would benefit from the new development, and that Letchworth would share the Government's vision of science in the service of the people.

\section{AMERICAN AWARDS TO BRITISH MEN OF SCIENCE}

WARDS have recently been made by the GovernA ment of the United States to the following British scientific workers, for their services during the War:

Medal of Freedom with Silver Palm: Sir Henry Dale, president during $1940-45$ of the Royal Society and a member of many important Government scientific committees; Sir Jack Drummond, director of research, Boots Pure Drug Co., Ltd., scientific adviser to the British Ministry of Food during 1944-46 ; Sir Alfred Egerton, professor of chemical technology, Imperial College of Science and Technology, London, for his work as a secretary of the Royal Society and member of the Scientific Advisory Committee to the War Cabinet; Sir Melvill Jones, Francis Mond professor of aeronautical engineering in the University of Cambridge, for scientific research and development, as an outstanding authority on the problems of aerial gunnery ; Dr. Alexander King, of the Ministry of Supply from early 1940, and head of the British Commonwealth Scientific Office in Washington from March 1944; Sir Edward Mellanby, secretary of the Medical Research Council, a principal figure in the organisation and conduct of British research in military medicine; Dr. Hugh M. Sinclair, lecturer in biochemistry, University of Oxford, sometime honorary nutritional consultant and co-ordinator of research in the British Zone, Control Commission (British Element) ; Mr. Cyril G. Trotman, for work as head of the Planning and Reporting Section of the Chemical Defence Experimental Station at Porton, and later as British representative on the international Project Co-ordination Staff in the United States ; Dr. Hector F. Willis, of the Admiralty Research Laboratory, Teddington, for scientific research and development in theoretical physics and particularly the transmission of sound.

Medal of Freedom with Bronze Palm: Sir Charles Darwin. director of the National Physical Laboratory, Teddington, and first head of the British Commonwealth Scientific Office in Washington, for service to scientific research and development; Mr. J. N. D. Heenan, for his work in the development of turbo-jet and turbine engines for use in U.S. Army Air Force aircraft ; Sir Ian Heilbron, professor of organic chemistry in the Imperial College of Science and Tech. nology, London, for scientific research and development in connexion with chemical warfare munitions; $\mathrm{Mr}$. Charles Lea, who was in charge of the development of incendiaries for the Ministry of Aircraft Production; Mr. Andrew Stratton, of the Royal Aircraft Establishment, South Farnborough, for research work in connexion with proximity fuses ; Mr. T. W. J. Taylor, for work in connexion with scientific research and development.

Medal of Freedom: Dr. James Craigie, of the Imperial Cancer Research Fund, associate professor of immunology and bacteriology at the University of Toronto, and member of the Joint United StatesCanadian Commission during June 1942-Feb. 1946; Mr. Amherst F. H. Thomson, representative of the Ministry of Supply, and later of the British Admiralty, for work in connexion with the development of proximity fuses.

\section{FORTHCOMING EVENTS}

(Meetings marked with an asterisk * are open to the public)

\section{Monday, February 9}

ROYAL SOCIrTY OF ARTS (at John Adam Street, Adelphi, London, W.C.2), at 4.30 p.m.-Sir Jack Drummond, F.R.S.: "Fats in the Life of the Nation" (Cantor Lecture).

UNIVHRSTTY OF LONDON (in the Assembly Hall, Institute of Education, Malet Street, London, W.C.1), at 5.30 p.m.-Prof. J. A. Lauwerys "International Co-operation in Education"."

INSTITOTION OF 'THR RUBBER INDUSTRY, MTDLAND SECTION (at the James Watt Memorial Institute, Great Charles Street, Birmingham), at 7.15 p.m.- Symposium on "Colour in the Rubber Industry" (Miss M. D. Gauntlett: "Physics and Measurement of Colour"; Mr. J Haworth: "Technology of Colour"; Mr. T. E. H. Gray : "Use and
Abuse of Colour").

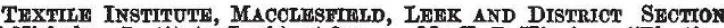
(at Nicholson Institute, Leek), at 8 p.m.-Mr. E. B. Higgins : "Plastics, Fabrics and Finishes", 